\title{
The Enlightenment of Deleuze's Generative Thought to Art Education Management in Colleges and Universities
}

\author{
Liying Shang \\ Fine Arts Academy \\ Jilin Normal University \\ SiPing, China \\ 369650978@qq.com
}

\author{
Rujuan Wang* \\ College of Humanities \& Sciences \\ Northeast Normal University \\ Changchun 130012, China \\ wangrujuan_1108@sina.com
}

\begin{abstract}
With the help of the generative thought of French philosopher Jill Deleuze, this paper reveals the Enlightenment of becoming thought to the management of art education in Colleges and universities through the definition of its concept and the generative orientation in the process of education management, so as to provide new thinking space and possibility of discussion for the management of Art Education.
\end{abstract}

Keywords-education management; generative thought; Art Education; generativity

\section{INTRODUCTION}

Art education management is the specific application of management discipline in the specific field of art education. It is a new discipline that studies the phenomenon of art education management and reveals the internal law of art education management. From the aspect of form, art education management is the result of the comprehensive intersection of art, education and management, and from the perspective of the discipline development process, it is the product of integration of education management and art [1]. Art education management is a relatively independent branch of education management system, and also follows the general rules of education management [2]. However, it mainly studies the subject, object, media, management mechanism and management mode of art education management, and discusses its operation track and development trend. However, to effectively carry out the management of art education, we must first abide by the internal laws and logic of art education; secondly, we need to have a certain understanding and cognition of the internal relations and essential attributes of art education [3]. This is the determination of the generativity of education management. Then, the determination of the generativity of education management will inevitably bring a lot of inspiration to the management of art education in Colleges and universities.

\section{DEFINITION OF BECOMING ThOUGHT IN EDUCATIONAL MANAGEMENT}

Generative is the process of the emergence, development and formation of new things. Heraclitus, an ancient dialectical theorist, first put forward the generative thought. Hegel developed this thought, but he was an idealist. He understood generative in a speculative and abstract way, rather than the generative of nature and matter. The generative understood by Marxist Leninist philosophy is the movement, change and development of nature and society. In the process of generative, new and progressive things always overcome the old and decadent things and are determined in life.

Furthermore, we can recognize that generative is not only different from presupposition in the form of development, but also explains that its essence is not static and abstract, but the process of existence [4]. In the process of existence, motivation and results are dialectical relations of the mutual premise. Therefore, Gilles Deleuze, a French philosopher, based on the thoughts of his predecessors, integrated his great achievements and formed the systematic theory of generative thought.

In the view of Deleuze, "generative" belongs to the concept of operational dynamics. It always wants us to establish an open magnetic field, which is in the field state of eliminating center. Deleuze once pointed out that "I always reorganize and deconstruct my concepts, repeat them and make them different from each other from the perspective of a movement, a center that is always decentralized, and an edge that is always moving". In other words, generation refers to not only a mechanism but also a process, innovation and edification. Just as in higher education, the responsibility of the school is to educate people not in the courses, but in the edification of an atmosphere, so as to cultivate people into a social person with modern ideas. A psychologist in the United States also believes that only a proper education at the right age is a real "person".

Therefore, we can confirm that the subject dimension in Deleuze's generative thought is generativity, that is, generativity dimension. The so-called "generativity dimension" means to see the problem from the perspective of generative thought, and take "generative" meaning as the perspective, scale, orientation and parameters to see the essential attributes of the subject. According to Deleuze, all the facts exist for a reason, pointing out that human beings need to reproduce the whole stage and mode of life generative in addition to thinking about life problems. If we look at the discipline of educational management from the perspective of generativity dimension, we should focus on the generative of life and explore the 
characteristics of its creativity and ethical science. This is closely related to life ethics and morality, and it is the key for individuals to express themselves freely. Therefore, in order to avoid confusing organization with management theory and fixed traditional technical procedures, we should firmly believe that theory needs to publicize human freedom. From this point of view, the analysis of generativity dimension at the political level is based on the premise of respecting the generative differences of life.

Then, the definition of the generativity dimension of education management is to extend, expand and connect generative thought to the field of education management, to rethink the problem of education management with "generative" as an important parameter, to put a series of philosophical concepts linked with "generative" into the problem scenarios of Education Management, and to connect the context of this field, It makes them constantly move in the thought space, creates all kinds of new connections, and breaks down the established and rigid oppressive mechanism. At the same time, the combination of fields and related industries enables philosophy concepts to penetrate and interact with each other, thus producing multiple types of innovative connection modes, and controlling the mandatory and solidified compression mode. Researchers believe that this is not the only way, but the most simple and powerful way.

\section{Generativity ORIENTATION IN THE PROCESS OF ART EDUCATION MANAGEMENT}

Art is a kind of generative, and art education naturally has a generativity attribute. As a continuous life art education management, it will show a generativity orientation. The orientation of generative thought is a "process" of movement, change, creation of difference, continuous construction of itself, including heterogeneity and diversity, rather than any teleological "end point" of completion. In other words, in the process of generative, generative thinking exists in a generativity way of thinking. It is in a permanent state of dynamic development.

As two basic orientations in educational management, the process and result have different historical development stages. The traditional education management (except for the education process management) basically inclines to the result orientation. The education process management pays attention to the process, emphasizes the process and the management process, which has the process orientation significance, but it only emphasizes the management of the education process and the link, the purpose is to control and realize the better education result and goal. Strictly speaking, it is a result orientation in essence, not a complete process orientation. In addition, most of the traditional education management tends to be result oriented, which aims to pursue certain results. The process is subordinate to the under of results. Whether it is scientific management, humanistic management, or other forms of education management, it is the same on the result orientation, but in the pursuit of different ways and methods, it is a result view under the linear thinking mode.

The generativity dimension of art education management is process oriented. The generative of education management is a kind of value pursuit, which pursues the generative of human value and meaning in education management, and takes education as the ultimate goal. The attribute of art education management generated by human value and meaning has a more aesthetic dimension than education management itself. Then, the generative process of art education management must reflect the aesthetic. This pursuit of value can only exist in the process of education management and be realized in the process of education management. The generative is a process of continuous expansion and variation, which is a process of continuous generative and acquisition of value and meaning. Therefore, the generative attribute of art education management is to base all management work on the process, decompose it into the process and realize it in the process. The whole process of education management is process oriented. Through the generativity dimension, we can grasp every link of every process of education management, that is, attach importance to the process, pay attention to the process, the transformation process, the breakthrough process and the creation process.

Here, we must make it clear that the insistence on the generative attribute of process oriented art education management does not exclude or negate the significance of result oriented. There is a harmonious dialectical materialism relationship between them. Based on the practical theory of Marxist philosophy, the generative attribute of art education management is an objective law that accords with the deep essence of education management. All the process and results of education management are in the process of generative, which fundamentally resolves the contradiction of quality and efficiency between generative management and preset management, democratic management and arbitrary management in art education management.

Therefore, the researchers believe that generativity is essential in the management of art education. It focuses on the practice, investment, persistence, responsibility, action and performance of all parties of education management in the process of education management, focuses on and grasps the integrity of education management, makes education management return to the standard and normal state, establishes the correct direction of education management, and makes "human" sense of mission coexist with national feelings and national destiny, so as to achieve the true significance and environment of education management. Therefore, we believe that the generative process orientation of educational management puts the results completely under the process and integrates them into the process, which conforms to and realizes the organic unity of the results and the process of educational management.

\section{GENERATIVITY: ENLIGHTENMENT FOR ART EDUCATION MANAGEMENT}

\section{A. To adopt a management mode that adapts to the generativity nature of Education}

Art is has generativity. When this kind of generativity is effectively manifested in art creation, it naturally has the generative spirit. Art education management belongs to education management [5] [6]. Then, in the process of art 
education management in Colleges and universities, the generative spirit is used to transform and enhance the education management, so as to promote the generative of its democratic, scientific and humanized characteristics, so as to create an "ecosystem" of mutual links, interaction and symbiosis. This is the premise of establishing the generativity management mode of education, and also the necessary foundation of establishing a virtuous circle education management system.

After taking the generative spirit as the premise and foundation of establishing the generativity management mode of education, and as the education manager occupying the main position in this process, we need to take communication, consultation, cooperation and participation to implement the education management and play its effective role. At the same time, in the process of implementing education management, managers should be aware of the actual needs and emotions of the managed and teachers and students, adjust and improve the management mode, fully understand the identity of their masters, help them occupy the main position in management, and improve their creativity and enthusiasm.

\section{B. To reconstruct the inner relationship of educational management with generative thought}

The generative thought is condensed by Deleuze after inheriting and aggregating the previous philosophical thoughts, and through deep thinking and practice summary. The application of generative thinking is to endow the management of art education in Colleges and universities with "generative character", to reorient and describe the concept of art education management with generative thinking, to reshape the form of organization and management activities, and to reconstruct the relationship between people in the organization and management system. Its goal is to wake up the sleeping self, heal the inner self and create the real self, so as to achieve the management situation of beauty and love, and present a more free life state.

However, for the management of art education in Colleges and universities, it is inevitable for the development of history and logic to move towards generative, which is the inherent quality of its own evolution, and also the path of change to be chosen based on the reflection of the current situation. Therefore, it is necessary to recognize the practical significance of the generative thought and apply it to the specific art education management. Specifically, the hierarchical subordination and subject object dual structure in education management should be eliminated, and the subject and related equal democratic relations and three-dimensional parallel structure should be rebuilt. Furthermore, we should create a diversified network ecological relationship within the education management, provide protection for the main position and value of all parties, and successfully create a set of interactive generative mechanism.

\section{To promote the de administration of education management with generative thought}

Over the past 70 years, the experience of higher education in China shows that there is always a phenomenon of centralized management between universities and the government [7]. Objectively speaking, in the relationship between universities and the government, universities are passive, and the government is active, which is shown by the administrative management mode of the government, that is, the administrative tendency. This fact inevitably leads to administrative management in education management, which often occurs when the higher level implements the management on the lower level [8]. For example, the Ministry of education has personnel management in the education department, the education department on the Education Bureau, as well as the school. It should be noted that most of the management related to the school, teachers, students and teaching does not belong to the administrative management Administrative management is only a rare existence. In most cases, we can not take this way, especially to put an end to the administrative management of education.

At present, in our country, there are often administrative ways to manage educational affairs. There are also many cases that managers regard themselves as officials. There are very serious administrative problems in education and management, which need enough attention in the field of education. Then, the solution to this problem needs to start from two aspects of theory and practice, but the premise is that we need to be fully aware of the adverse effects brought by this problem.

Therefore, the use of generative thought in the management of art education in Colleges and universities, from a new perspective to study the internal laws and logic of education, we can find the generativity, and establish the generative character of education. As a result, the administrative phenomenon in the education system will lose its foundation, and will be gradually eliminated with the development of time, and finally return to the education standard, giving education management a new life state.

\section{To liberate human nature in education management by generative thought}

Human nature is the nature of human beings, and it is a common thing in daily use. But people who are born must face a clear theme. When art makes people "human", it is art that liberates people in the process of generative. Let people know the self, the ID, the superego, and the present significance of the existence of the real self. When people receive certain education, they will have new human cognition or unique feelings. In Marxist thought, the content of the Communist social freedom is to achieve the liberation of human nature, which is also a way for everyone to achieve comprehensive and free development, and also an ultimate goal in the field of education. In this way, human nature naturally appears in the process of generative. And art education makes more people understand the existence of this fact.

However, in education management, the decisive factor is people. The liberation of human nature can help education management work, and it is also the ultimate goal. Since entering the modern society, the school education has appeared the expansion trend of externalization and scientific rationality, and the education management is more and more towards the direction of formalization, institutionalization, stratification and 


\section{ACKNOWLEDGMENT}

conscientization, which in turn has created a constraint on the development of human nature.

Generative can provide help and support for the liberation of human nature. It believes that compared with form, content is the most important; it can reduce the rigidity of system and increase the flexibility of management; it can eliminate the bureaucracy in management organization and replace it with flattening; it advocates the essence of humanity and scientific defects have been effectively remedied. Generative has vigorously promoted the subjectivity of all parties in education management, cleared the obstacles set by the mechanism and system, fully explored the potential of human beings, liberated human nature, and fully mobilized the internal power and vitality of education management. Therefore, it is necessary to liberate human nature in education management.

\section{CONCLUSION}

To sum up, many facts and experiences tell us profoundly that the essence beyond generative is generative itself. We have to obey the belief, and naturally to do, to find its internal motivation, generative must exist in all education, management, that is to say, the generated to education, to management, in order to generative, then education and management. Only in this way, can we really achieve high quality life value management.
This work was partially supported by Master and Doctor start project of Jilin Normal University and 2020 humanities and social sciences research planning fund project of the Ministry of Education.

\section{REFERENCES}

[1] Xiang X. Notice of Retraction Existing problems and solutions of public art education management in colleges[C]// International Conference on Artificial Intelligence. IEEE, 2011.

[2] Kehk Bee Lian. Art Education in Singapore[M]// The International Encyclopedia of Art and Design Education. American Cancer Society, 2019.

[3] Irgens, Eirik J. Art, science and the challenge of management education [J]. Scandinavian Journal of Management, 2014, 30(1):86-94.

[4] Alton Y.K. Chua, Swee Kiang Heng. A knowledge management perspective on Art Education [J]. International Journal of Information Management, 2009, 30(4).

[5] Fen g Qi. Status university art character education management system and Countermeasures [A]. Proceedings of 2017 World Symposium on Economics, Business and Management (WSEBM 2017)[C].2017:6.

[6] Jing Xie. Research on the Influence of Information on the Education Management of Art Design Major [A]. Institute of Management Science and Industrial Engineering. Proceedings of 2019 9th International Conference on Education and Management(ICEM 2019)[C].Institute of Management Science and Industrial Engineering, Computer Science and Electronic Technology International Society,2019:6.

[7] Xiaofei W. Development of Design and Art Education Model in China[J]. Journal of Landscape Research, 2014(Z2).

[8] Ingrid Molderez, Kim Ceulemans. The power of art to foster systems thinking, one of the key competencies of education for sustainable development [J]. Journal of Cleaner Production, 2018,186. 